\title{
HEALTH AND ECONOMIC IMPACTS OF OZONE SHIP-RELATED AIR POLLUTION IN PORTUGAL
}

\author{
RAFAEL A. O. NUNES ${ }^{1}$, MARIA C. M. ALVIM-FERRAZ ${ }^{1}$, FERNANDO G. MARTINS ${ }^{1}$, \\ JUKKA-PEKKA JALKANEN ${ }^{2}$, HANNA HANNUNIEMI ${ }^{2}$ \& SOFIA I. V. SOUSA ${ }^{1}$ \\ ${ }^{1}$ LEPABE - Laboratory for Process, Environment, Biotechnology and Energy, \\ Faculty of Engineering, University of Porto (FEUP), Portugal \\ ${ }^{2}$ Finnish Meteorological Institute, Finland
}

\begin{abstract}
Air pollution is the leading cause of the global burden of disease from the environment, entailing substantial economic consequences. International shipping is a significant source of $\mathrm{NO}_{\mathrm{x}}, \mathrm{SO}_{2}, \mathrm{CO}$ and $\mathrm{PM}$, which contributes to the increase in $\mathrm{O}_{3}$ levels that can cause known negative health impacts. Thus, this study aimed to estimate the health impacts of ozone ship-related air pollution in Portugal in 2015. To determine the health-related effects of this sector, shipping emissions were obtained from an Automatic Identification System based emission inventory using the Ship Traffic Emission Assessment Model (STEAM). Their contributions to SOMO35 (sum of ozone daily 8-h maximum means over $35 \mathrm{ppb}$ in the calendar year, expressed in ppb per day) levels in Portugal were modelled using the EMEP/MSC-W chemistry transport model (simulations with and without shipping emissions). Log-linear functions based on WHO-HRAPIE relative risks for each health endpoint (all-cause and respiratory mortality, and cardiovascular and respiratory hospital admissions) were used to estimate the attributable fractions. Then, the excess burden of disease was calculated by multiplying the attributable fractions with the baseline incidence of each health endpoint and the population at LAU2 level. Costs associated with the health impacts were estimated as the product of the excess burden of disease and its unit health cost value. Shipping emissions contributed to an increase of $21 \%$ in the number of deaths for all-cause mortality and respiratory diseases, as well as hospital admissions for cardiovascular and respiratory diseases. A total external cost of around 180 (86-266) M€ a yr-1 was estimated for these health endpoints in 2015. These results show that $\mathrm{O}_{3}$-related air pollution from ships is a considerable problem affecting the Portuguese population.
\end{abstract}

Keywords: shipping emissions, modelling, air pollution, impact pathway approach, health effects.

\section{INTRODUCTION}

International shipping has been recognized as a significant source of pollution namely concerning nitrogen oxides $\left(\mathrm{NO}_{\mathrm{x}}\right)$, sulphur oxides $\left(\mathrm{SO}_{\mathrm{x}}\right), \mathrm{CO}$ and particulate matter $(\mathrm{PM})$, also contributing to the increase of $\mathrm{O}_{3}$ levels. Nevertheless, the associated effects on premature mortality and morbidity are not yet well documented [1]-[4]. Once 70\% of emissions from ships in international routes occur until $400 \mathrm{~km}$ from the coast and can be easily transferred hundreds of kilometres towards the mainland, ships have the potential to contribute significantly to air quality degradation and consequent effects on human health in coastal areas, as well as in inner areas [2], [5]. Shipping emissions are regulated by the International Maritime Organization (IMO) according to the Annex VI "Prevention of Air Pollution from Ships" under the International Convention for the Prevention of Pollution from Ships (MARPOL) [6]. For Portugal, air quality standards for ambient air are defined in Decreto-Lei $n^{\circ}$ 102/2010, which imposes limits for human health protection [7].

In the last 25 years, emissions from land-based sources (traffic, heating, industrial production, power generation, etc.) have decreased substantially in Europe due to new and more effective air pollution and climate policies. Emissions of $\mathrm{NO}_{\mathrm{x}}, \mathrm{SO}_{\mathrm{x}}$ and fine particulate matter have been reduced by about $52 \%, 83 \%$ and $28 \%$, respectively [8], [9]. An opposite behaviour was verified for ship emissions which have been neglected for a long time, making 
shipping one of the least and last regulated anthropogenic emission sources [8], [10], [11]. Therefore, significant progress has been made to study air quality impact of ship emissions all over the world, however only a few also studied their negative effects on human health [1], [3], [12]-[14]. Since studies on the impact of ship emissions on human health are still scarce and Portugal has a very important geo strategic position in international maritime transport, it is relevant to study the impacts of ship emissions on health in this region. Moreover, as far as known there are no studies concerning health impacts of ozone ship-related air pollution in Portugal. Thus, this study aimed to reduce this gap by estimating the health impacts of ozone ship-related air pollution in Portugal for 2015.

\section{MATERIALS AND METHODS}

\subsection{Ship emissions inventory}

The shipping emissions inventory of Portugal for 2015 was obtained based on the full bottom-up Ship Traffic Emission Assessment Model (STEAM). STEAM allows to assess emissions from each individual ship combining the Automatic Identification System (AIS) shipping activity information (both terrestrial and satellite-based, provided by Orbcomm) with the detailed technical characteristics of each ship and engine type (collected from various sources and archived for over 90,000 ships) and emission factors of a particular ship type, size, machinery type and operative mode. Based on this information, the model can predict the power consumptions and loads of main and auxiliary engines and the fuel consumption of the ship with reasonableness based on resistance that each ship requires to overcome at a specified speed [15].

\subsection{Atmospheric simulations}

To evaluate the contributions of shipping emissions on $\mathrm{O}_{3}$ concentrations over Portugal, atmospheric simulations have been performed with the chemical transport model EMEP/MSC-W. The model was configured for two scenarios, with (w/ship case) and without shipping emissions (wt/ship case) for 2015 with a horizontal resolution of $0.1^{\circ} \times 0.1^{\circ}$ (longlat), vertical structure of the model with 34 layers and a data output time step of $1 \mathrm{~h}$. Grid emissions in the same resolution from other sources divided in 11 SNAP (Selected Nomenclature for Air Pollution) sectors like public power, industry, other stationary combustion, road transport among others were taken from official European emission inventories provided by the Centre on Emission Inventories and Projection (CEIP) that are reported under the Convention on Long-range Transboundary Air Pollution (CLRTAP) and National Emission Ceilings (NEC) Directive [15]. Emissions from shipping sector considered in the CEIP inventory were excluded to perform the simulations. Moreover, contribution to emissions of the dust from Sahara, emissions of $\mathrm{NO}_{\mathrm{x}}$ from lightning and emissions from forest and vegetation fires from the "Fire INventory from NCAR version 1.5" [16] were also considered. More details on the model can be found in Simpson et al. [17] and NMI [18]. The meteorological data for 2015 was generated by the state-of-the-art Integrated Forecast System model (IFS) of the European Centre for Medium-Range Weather forecasts (ECMWF).

\subsection{Health impact assessment}

To assess the excess of health burden attributable to ozone ship-related air pollution SOMO35 indicator (sum of ozone daily 8 -h maximum means over $35 \mathrm{ppb}$ in the calendar 
year, expressed in ppb per day) was used. SOMO35 was applied because it is considered the most robust indicator for $\mathrm{O}_{3}$ health impact assessments in global model calculations [19]. Log-linear functions (based on WHO-HRAPIE relative risks) for each health endpoint (derived from available epidemiologic studies) were used to estimate the relative risks (RR), as recommended by WHO [20] and other authors [21]-[25]. RR for linear-log functions were estimated using the following equation:

$$
R R_{\text {log-linear }}=e^{\beta\left(C-C_{0}\right)},
$$

where $C$ is the SOMO35 level (converted to $\mu \mathrm{g} \mathrm{m}^{-3}$ ), $C_{0}$ cut-off value (considered zero in calculations) and $\beta$-coefficient relates the change in the RR to a unit change in air pollutant concentration (an increase of the risk per $10 \mu \mathrm{g} \mathrm{m}^{-3}$ ).

After RR calculations, the attributable fractions (AF) were calculated following the attributable risk as:

$$
A F=(R R-1) / R R \text {. }
$$

To estimate the excess burden of disease (EBD) the increment in the number of deaths and additional cases due to ozone ship-related air pollution over 2015 was estimated, using eqn (3):

$$
\triangle E B D s=B I \times A F \times P o p,
$$

where $B I$ is the baseline incidence of the selected health endpoint for a given population and $P o p$ is the population within the age group of interest.

Data about population by single year of age of Portugal at LAU2 level (civil parish) was obtained from the Eurostat 2011 Census database hub [26].

All-cause mortality baseline rate was obtained from the National Statistical System of Portugal for 2015 (INE, 2018). Respiratory mortality baseline rate was obtained from the European Health for All database (HFA-DB). Data on hospital admissions for respiratory and cardiovascular causes was taken from the OECD Stat database [27]. Health endpoints, baseline incidences, and RR used in this study are listed in Table 1.

\subsection{Assessment of socio-economic external costs of the burden of disease}

To estimate the economic cost, the burden of disease unit health costs (cost per case of illness) were used. The exposure cost for a particular health endpoint was calculated as the product of the Exposure Response Function (ERF) and its unit health cost value (eqn (4)).

Table 1: Health endpoints, baseline incidences, and RR used in this study.

\begin{tabular}{|l|c|c|c|}
\hline Health endpoints & Age group & BI per $10^{5}$ & RR (95\% CI) \\
\hline All-cause mortality & Adults (age $\geq 30$ years) & 1,048 & $1.0029(1.0014-1.0043)$ \\
\cline { 2 - 3 } Respiratory mortality & 30 to 44 years & 3.0 & \multirow{2}{*}{$1.014(1.005-1.024)$} \\
\cline { 2 - 3 } & 45 to 59 years & 16.4 & 76.3 \\
\cline { 2 - 3 } & 60 to 74 years & 976.2 & \\
\hline $\begin{array}{l}\text { Cardiovascular } \\
\text { hospital admissions }\end{array}$ & $75+$ years & $1,112.4$ & $1.0089(1.0050-1.0127)$ \\
\hline $\begin{array}{l}\text { Respiratory hospital } \\
\text { admissions }\end{array}$ & $>64$ years & 919.1 & $1.0044(1.0007-1.0083)$ \\
\hline
\end{tabular}

$\mathrm{BI}=$ baseline incidence; $\mathrm{RR}=$ relative risk $\mathrm{CI}$ = confidence interval. 


$$
\text { Exposure cost }=(E R F) \times(\text { Cost per case of illness or death }) .
$$

Deaths were valued using the value of statistical life (VSL), which is how much society is willing to pay to avoid an anonymous death [28].

Following the benefit transfer approach that takes into account differences in income levels between two places, country-specific VSL for Portugal in 2015 was estimated using the formula recommended in OECD [29], based on an extensive meta-study performed by OECD [30]. VSL was adjusted according to the eqn (5).

$$
V S L C 2015=V S L E U 2005 \times\left(\frac{Y C}{Y E U}\right)^{\beta} \times(1+\Delta P+\Delta Y)^{\beta},
$$

where: VSL EU 2005 is the VSL of the average of EU27 countries (USD 3.6 million in 2005); $Y C$ is the Gross Domestic Product (GDP) per capita at the purchasing power parity (PPP) in 2015; YEU is the average GDP per capita of EU27 countries at PPP in 2015; $\beta$ is the income elasticity of VSL, which measures the percentage increase in VSL for a percentage increase in income (the value of 0.8 was established by OECD); PPP is the purchasing power parity-adjusted exchange rate in $2005 ; \Delta \mathrm{P}$ is the percentage increase in consumer price from year 2005 to 2015 (measured by consumer price index (CPI) that reflects the inflation or changes in the cost to the average consumer of acquiring a basket of goods and services); and $\Delta Y$ is the percentage change in real GDP per capita growth from the reference year to 2015 (derived from real GDP per capita annual growth). All values previously described were obtained for the reference years and 2015 from the OECD data portal [31]. Table 2 summarizes the unit values used in this study.

Table 2: Unit cost values for VSL and respiratory and cardiovascular hospital admissions used in this study.

\begin{tabular}{|l|c|c|}
\hline Parameter & Unit value & Units \\
\hline Value of Statistical Life (VSL) & 2.60 & M€/death \\
\hline Respiratory hospital admissions & 2414 & $€ /$ hospital admission \\
\hline Cardiovascular hospital admissions & 2414 & $€ /$ hospital admission \\
\hline
\end{tabular}

\section{RESULTS AND DISCUSSION}

Table 3 presents the estimated number of premature deaths and additional cases associated with exposure to ozone ship-related air pollution for 2015 in Portugal, as well as the external costs. Fig. 1(a)-(d) shows the spatial distribution of premature deaths and additional cases.

Additional 69 (95\% CI: 33, 102) deaths due to all causes, 34 (95\% CI: 12, 57) deaths due to respiratory diseases, as well as 46 (95\% CI: 26, 66) and 23 (95\% CI: 4, 43) hospital admissions due to cardiovascular and respiratory diseases, respectively, were estimated due to ozone ship-related air pollution for 2015 in Portugal. Overall, shipping emissions contributed to increase in $21 \%$ the number of deaths and additional cases of all health endpoints considered. As can be seen from Fig. 1, most mortality and additional cases occurred close to Portugal coastline. These results seemed to be related with a greater susceptibility of these zones to shipping emissions and because those are densely populated areas. It is also important to emphasise that results showed additional cases of hospital admissions due to respiratory diseases in some inner parishes of Portugal. The number of deaths due to respiratory diseases and the number of hospital admissions due to cardiovascular and respiratory diseases were compared with the total number of deaths and 
Table 3: Total number of additional cases and external costs in Portugal associated with ozone ship-related air pollution in 2015 .

\begin{tabular}{|c|c|c|c|}
\hline $\begin{array}{c}\text { Air } \\
\text { pollutant }\end{array}$ & Health endpoint & $\begin{array}{c}\text { Additional deaths/cases } \\
(95 \% \mathrm{CI})\end{array}$ & $\begin{array}{c}\text { External costs }(95 \% \mathrm{CI}) \\
\text { (values in M€) }\end{array}$ \\
\cline { 2 - 4 } & All-cause mortality & $69(33-102)$ & $179(85.7-265)$ \\
\cline { 2 - 4 } $\mathrm{O}_{3}$ & $\begin{array}{c}\text { Respiratory } \\
\text { mortality }\end{array}$ & $34(12-57)$ & $88.4(31.2-148)$ \\
\cline { 2 - 4 } & $\begin{array}{c}\text { Cardiovascular } \\
\text { hospital admissions }\end{array}$ & $46(26-66)$ & $0.111(0.0628-0.159)$ \\
\cline { 2 - 4 } & $\begin{array}{c}\text { Respiratory hospital } \\
\text { admissions }\end{array}$ & $23(4-43)$ & $0.0555(0.096 .6-0.104)$ \\
\hline
\end{tabular}

$\mathrm{CI}=$ confidence interval.

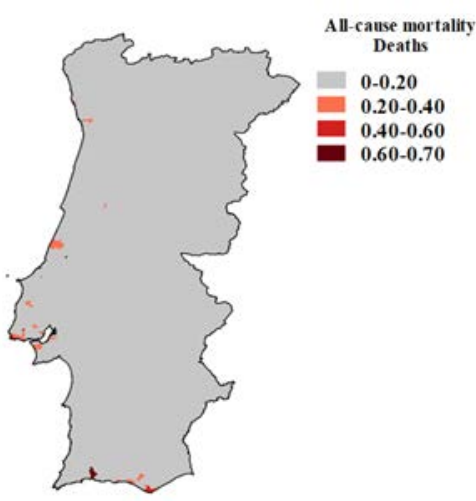

(a)

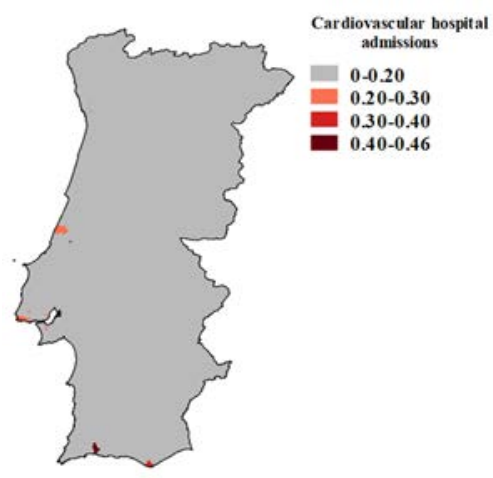

(c)

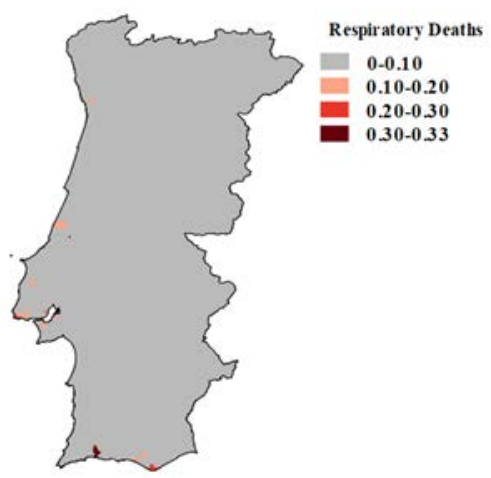

(b)

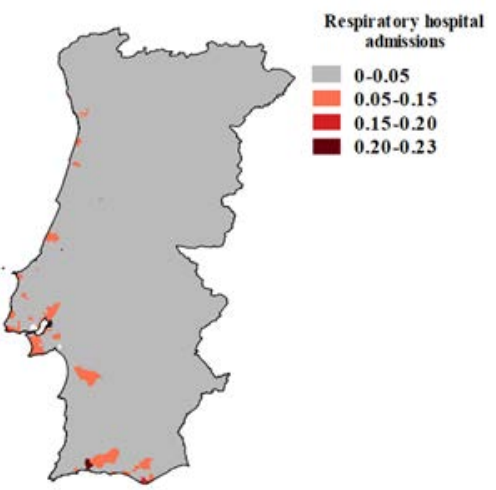

(d)

Figure 1: Spatial distribution (at LAU2 level) of: (a) Deaths due to all causes; (b) Deaths due to diseases of respiratory system; (c) Hospital admissions due to diseases of cardiovascular system; and (d) Hospital admissions due to diseases of respiratory system. 
additional cases reported for Portugal during 2015. According to the results, the number of deaths due to respiratory diseases and the additional cases due to diseases of cardiovascular and respiratory systems attributable to ozone ship-related exposure represented $0.3 \%, 0.2 \%$ and $0.1 \%$ of the total, respectively. Moreover, and more specifically, the number of deaths calculated from all-cause mortality was compared with the number of premature deaths attributable to $\mathrm{O}_{3}$ exposure during 2015 for Portugal reported on the Air quality in Europe - 2018 report performed by the European Environmental Agency (EEA). Results showed that the number of deaths due to $\mathrm{O}_{3}$ ship-related exposure calculated in this study represented $23 \%$ of the total number of deaths reported by the EEA. Results confirm that $\mathrm{O}_{3}$ related air pollution from ships seemed to be a considerable problem affecting the Portuguese population, mainly in coastal areas.

Regarding exposure costs, it was estimated $79 \mathrm{M} €(95 \% \mathrm{CI}: 85.7-265 \mathrm{M} €)$ related with the number of additional deaths from all causes, $88.4 \mathrm{M€}(95 \% \mathrm{CI}$ : 31.2-148 M€) from deaths due to respiratory diseases as well as $0.111 \mathrm{M€}(95 \% \mathrm{CI}: 0.0628-0.159 \mathrm{M} €)$ and $0.0555 \mathrm{M} €$ (95\% CI: $0.096 .6 €-0.104 \mathrm{M} €$ ) related with additional hospital admissions due to cardiovascular and respiratory diseases, respectively. A total exposure cost of around $180 \mathrm{M} € \mathrm{yr}^{-1}$ (95\% CI: 86-266 $\left.\mathrm{M} \mathrm{yr}^{-1}\right)$ resulting of $\mathrm{O}_{3}$ related air pollution from ships was estimated in Portugal for 2015 (respiratory mortality could not be added to the overall costs estimate to avoid double counting). The results above described show that human health external costs due to $\mathrm{O}_{3}$ related air pollution from ships cannot be neglected when the total external costs of shipping emissions are considered.

\section{CONCLUSIONS}

This study allowed estimating health and economic impacts of ozone ship-related air pollution in Portugal for 2015. It was estimated 69 (95\% CI: 33-102) deaths and costs of 79 M€ (95\% CI: 85.7-265 M€) due to all causes, 34 (95\% CI: 12-57) deaths and costs of 88.4 M€ (95\% CI: 31.2-148 M€) from deaths due to respiratory diseases, 46 (95\% CI: 2,666) and 23 (95\% CI: 4.43) hospital admissions and costs of $0.111 \mathrm{M€} \mathrm{(95 \%} \mathrm{CI:} \mathrm{0.0628-0.159} \mathrm{M€)}$ and $0.0555 \mathrm{M} €(95 \% \mathrm{CI}: 0.096 .6 €-0.104 \mathrm{M} €)$ due to cardiovascular and respiratory diseases, respectively, due to ozone ship-related air pollution. A total exposure cost of around $180 \mathrm{M} €$ $\mathrm{yr}^{-1}$ (95\% CI: $86-266 \mathrm{M} \mathrm{yr}^{-1}$ ) was estimated in Portugal for 2015. This study shows that ozone ship-related air pollution increased $21 \%$ the number of deaths and cases of all health endpoints. Moreover, the number of deaths due to ozone ship-related exposure calculated in this study represented $23 \%$ of the total number of deaths reported by the EEA for Portugal in 2015, which confirms that ship emissions may have a substantial impact on human health, mainly, in areas with high population density and near the Portuguese coastline. These findings contribute to the understanding of the comprehensive impacts of ozone ship-related air pollution, supporting the view that shipping emissions are a significant source air pollution that affects the Portuguese population.

Future developments should include the study of other air pollutants and of different health endpoints, as well as extend the study to the Iberian Peninsula domain.

\section{ACKNOWLEDGEMENTS}

This work was financially supported by: project UID/EQU/00511/2019 - Laboratory for Process Engineering, Environment, Biotechnology and Energy - LEPABE funded by national funds through FCT/MCTES (PIDDAC); project "LEPABE-2-ECO-INNOVATION" - NORTE-01-0145-FEDER-000005, funded by Norte Portugal Regional Operational Programme (NORTE 2020), under PORTUGAL 2020 Partnership Agreement, through the European Regional Development Fund (ERDF) and project EMISSHIP (POCI - 01 - 0145 - FEDER - 032201), 
funded by FEDER funds through COMPETE2020 - Programa Operacional Competitividade e Internacionalização (POCI) and by national funds (PIDDAC) through FCT/MCTES.

\section{REFERENCES}

[1] Brandt, J. et al., Assessment of past, present and future health-cost externalities of air pollution in Europe and the contribution from international ship traffic using the EVA model system. Atmospheric Chemistry Physics, 13, pp. 7747-7764, 2013.

[2] Corbett, J.J., Winebrake, J.J., Green, E.H., Kasibhatla, P., Eyring, V. \& Lauer, A., Mortality from ship emissions: A global assessment. Environmental Science \& Technology, 41, pp. 8512-8518, 2007.

[3] Sofiev, M. et al., Cleaner fuels for ships provide public health benefits with climate tradeoffs. Nature Communications, 9, 2018.

[4] Nunes, R.A.O., Alvim-Ferraz, M.C.M., Martins, F.G. \& Sousa, S.I.V., Assessment of shipping emissions on four ports of Portugal. Environmental Pollution, 231(2), pp. 1370-1379, 2017.

[5] Eyring, V. et al., Transport impacts on atmosphere and climate: Shipping. Atmospheric Environment, 44, pp. 4735-4771, 2009.

[6] International Maritime Organization (IMO), Prevention of Air Pollution from Ships. www.imo.org/en/OurWork/Environment/PollutionPrevention/AirPollution/Pages/AirPollution.aspx. Accessed on: 11 Apr. 2018.

[7] Decreto-Lei $n^{o} 102 / 2010$. Diário da República 1. a série $-\mathrm{N}^{\circ} 186$. Ministério do Ambiente e do Ordenamento do Território.

[8] Aulinger, A., Matthias, V., Zeretzke, M., Bieser, J., Quante, M. \& Backes, A., The impact of shipping emissions on air pollution in the greater North Sea region - Part 1: Current emissions and concentrations. Atmospheric Chemistry Physics, 16, pp. 739758, 2016.

[9] European Environment Agency (EEA), Emissions of the Main Air Pollutants in Europe, Copenhagen, 2017.

[10] Aksoyoglu, S., Baltensperger, U. \& Prévôt, A.S.H., Contribution of ship emissions to the concentration and deposition of air pollutants in Europe. Atmospheric Chemistry Physics, 16, pp. 1895-1906, 2016.

[11] Chen, D. et al., Contribution of ship emissions to the concentration of $\mathrm{PM}_{2.5}$ : A comprehensive study using AIS data and WRF/Chem model in Bohai Rim Region, China. Science Total Environment, 610-611, pp. 1476-1486, 2018.

[12] Jonson, J.E., Jalkanen, J.-P., Johansson, L., Gauss, M. \& Van Der Gon, H.A.C.D., Model calculations of the effects of present and future emissions of air pollutants from shipping in the Baltic Sea and the North Sea. Atmospheric Chemistry Physics, 15, pp. 783-798, 2015.

[13] Antturi, J. et al., Costs and benefits of low-sulphur fuel standard for Baltic Sea shipping. Journal of Environmental Management, 184, pp. 431-440, 2016.

[14] Liu, H. et al., Health and climate impacts of ocean-going vessels in East Asia. Nature Climate Change, 6, pp. 1037-1041, 2016.

[15] EMEP/CEIP, Emissions as used in EMEP models. www.ceip.at $/ \mathrm{ms} / \mathrm{ceip}$ home1/ceip_ home/webdab_emepdatabase/emissions_emepmodels/. Accessed on: 10 Feb. 2019.

[16] Wiedinmyer, $\bar{C}$. et al., The Fire INventory from NCAR (FINN): a high resolution global model to estimate the emissions from open burning. Geoscientific Model Development, 4, pp. 625-641, 2011.

[17] Simpson, D. et al., The EMEP MSC-W chemical transport model - Technical description. Atmospheric Chemistry Physics, 12, pp. 7825-7865, 2012. 
[18] Norwegian Meteorological Institute (NMI), EMEP/MSC-W Model Unofficial User's Guide, 2017.

[19] Faridi, S. et al., Long-term trends and health impact of $\mathrm{PM}_{2.5}$ and $\mathrm{O}_{3}$ in Tehran, Iran, 2006-2015. Environmental International, 114, pp. 37-49, 2018.

[20] World Health Organization (WHO), AirQ+: Software Tool for Health Risk Assessment of Air Pollution. www.euro.who.int/en/health-topics/environment-and-health/airquality/activities/airq-software-tool-for-health-risk-assessment-of-air-pollution. Accessed on: 25 Feb. 2019.

[21] Li, Y., Henze, D.K., Jack, D. \& Kinney, P.L., The influence of air quality model resolution on health impact assessment for fine particulate matter and its components. Air Quality, Atmosphere \& Health, 9, pp. 51-68, 2016.

[22] Cárdaba Arranz, M., Muñoz Moreno, M.F., Armentia Medina, A., Alonso Capitán, M., Carreras Vaquer, F. \& Almaraz Gómez, A., Health impact assessment of air pollution in Valladolid, Spain. BMJ Open, 4, p. e005999, 2014.

[23] Natalie, M. et al., Urban and transport planning related exposures and mortality: A health impact assessment for cities. Environmental Health Perspectives, 125, pp. 8996, 2017.

[24] Anenberg, S.C. et al., Survey of ambient air pollution health risk assessment tools. Risk Analysis, 36, pp. 1718-1736, 2016.

[25] Yorifuji, T. et al., Health impact assessment of $\mathrm{PM}_{10}$ and $\mathrm{PM}_{2.5}$ in 27 southeast and east Asian cities. Journal of Occupational and Environmental Medicine, 57, 2015.

[26] European Statistical System (ESS), 2011 Census Hub, 2011 Census database. https://ec.europa.eu/CensusHub2/query.do?step=selectHyperCube\&qhc=false. Accessed on: 25 Feb. 2019.

[27] Organisation for Economic Co-operation and Development (OECD), Health Status. https://stats.oecd.org/index.aspx?queryid=30123\#. Accessed on: 25 Feb. 2019.

[28] Organisation for Economic Co-operation and Development (OECD), Valuing Mortality Risk Reductions in Regulatory Analysis of Environmental, Health and Transport Policies: Policy Implications, 2011.

[29] Organisation for Economic Co-operation and Development (OECD), The Cost of Air Pollution Health Impacts of Road Transport, 2014.

[30] Organisation for Economic Co-operation and Development (OECD), Mortality Risk Valuation in Environment, Health and Transport Policies, 2012.

[31] Organisation for Economic Co-operation and Development (OECD), OECD Data. https://data.oecd.org/. Accessed on: 25 Feb. 2019. 